\title{
The Mental Origins and the Evolution of Political Order
}

\author{
Dingyu Chung \\ Utica, Michigan, USA \\ Email: dy_chung@yahoo.com
}

How to cite this paper: Chung, D.Y. (2019) The Mental Origins and the Evolution of Political Order. Journal of Behavioral and Brain Science, 9, 211-245.

https://doi.org/10.4236/jbbs.2019.96018

Received: April 25, 2019

Accepted: May 26, 2019

Published: May 29, 2019

Copyright $\odot 2019$ by author(s) and Scientific Research Publishing Inc. This work is licensed under the Creative Commons Attribution International License (CC BY 4.0).

http://creativecommons.org/licenses/by/4.0/

\begin{abstract}
The paper proposes that the four-component structure of political order consists of state, imagination, rule, and accountability whose mental origins are the social brain, theory of mind, the rational brain, and the empirical brain, respectively. The rational brain and the empirical brain are from the thinking brain. This paper posits that in the evolution of political order, the main function of political order is to pacify changed social structure derived from technological revolution. Therefore, the four technological revolutions (the Upper Paleolithic, Agricultural-Bronze, Iron, and Industrial Revolutions) produce the four changed social structures (linked bands, tribe, mega empire, and modern nation, respectively) whose internal conflicts are pacified by the four political revolutions (the imaginative, hierarchical, thinking, bottom-up political revolutions, respectively) to form the four politics (the imaginative egalitarianism, decentralized hierarchical tribalism, centralized top-down thinking, and multilateral bottom-up thinking politics, respectively). In the competitive West originated from Greece and Middle East, the rule of law is the rational rule of competition among competitors, and the accountability of election is the empirical accountability of competition among competitors. In the cooperative East originated from India and China, the rule of relation is the rational rule of cooperation among kin-friends, and the accountability of professional qualification is the empirical accountability of cooperation among kin-friends. For political order, the two viable politics are competitive liberal democracy based on liberty and cooperative well-off democracy (well-off socialism) based on wellbeing. The direction of political order is middle democracy between liberal democracy and well-off democracy based on the multilateral bottom-up thinking politics.
\end{abstract}

\section{Keywords}

Political Order, Evolution, Mental Origins, Social Brain, Political Brain, Theory of Mind, Politics, Democracy 


\section{Introduction}

According to Francis Fukuyama [1] [2], political order of liberal democracy consists of three components: the state, the independent rule of law, and the independent accountability of election. A successful liberal democracy combines the three components in perfect balance. State as central authority is strong, but it is bound by a transparent system of rule of law and accountability of election to the will of the people. The book [1] traces the development of political order from the earliest human societies, which were small bands of hunter-gatherers. The original default state of hunter-gatherers was built on sociability derived from kin selection and reciprocal altruism. The first major social development was the transition from hunter-gatherer bands to tribes, made possible by the religion of common ancestors that united large numbers of bands. Warfare also forced the second major social transition, from decentralized tribes to centralized states which offered a better chance of survival. Much of the book's analysis concerns how states develop from tribes. Different states have incorporated the three components of political order differently. Of the European powers, only England and Denmark [2] developed a strong state, the rule of law, and mechanisms to hold the ruler accountable. This successful formula then became adopted by other European states.

Since according to Fukuyama, tribes were formed by the religion of common ancestors to link bands together, religion should be a component of political order. Therefore, the four components of political order are state, religion of common ancestors, the rule of law, and the accountability of election for liberal democracy. Liberal democracy is essentially the product of the competitive Western culture originated from the Middle East and Greece. The books by Fukuyama appear to use political order to justify liberal democracy. The Western components of state, religion, the rule of law, and the accountability of election can be transformed into the generalized components of state, imagination, rule, and accountability for all cultures. For all cultures, state is based on the original default state of hunter-gatherers derived from social instincts, such as kin selection and reciprocal altruism. State is the core organization of government. The social component of state is social conscience. Political identity larger than bands in hunter-gatherers is just human imagination. Imagination provides the identity of government larger than the band in the primitive human society. The primitive band of hunter-gatherers did not need imagination for its political identity. The social component of imagination is social dream. Rule can be the rule of law in the competitive West or the rule of relation in the cooperative East originated from India and China. Rule provides the rules for a good and functional large and complex government. A small and simple government does not need explicit rules. The social component of rule is social rule. Accountability can be the accountability of election in the West or the accountability of professional qualification in the East. Accountability is to objectively verify a good and functional large and complex government. A small and simple government does 
not need explicit accountability. The social component of accountability is social accountability. Therefore, the paper proposes that the generalized four-component structure of political order consists of state (social conscience), imagination (social dream), rule (social rule), and accountability (social accountability).

The paper proposes that the mental origins of the generalized four-component structure of political order consisting of state, imagination, rule, and accountability are the social brain [3], theory of mind, the rational brain with priories, and the empirical brain without priories, respectively as in Table 1 . The rational brain and the empirical brain are the parts of the thinking brain with deliberation, precision, reason. The thinking brain is important to establish proper rule and accountability. State and imagination are derived mostly from the emotional-instinctive brain. Rule and accountability from the thinking brain modify state and imagination from the emotional-instinctive brain. The solid foundation of political order can be built on the mental origins of political order.

This paper deals with the evolution of political order. This paper posits that in the evolution of political order, the main function of political order is to pacify changed social structure derived from technological revolution. An initial social structure with simple technology is converted into a transitional social structure with complex technology through technological revolution. Complex technology induces changed network for the production-distribution of complex technology, and produces technology-driven changed social structure. The changed social structure inevitably produces internal conflict, resulting in disordered changed social structure. Such internal conflicted is pacified by pacifying politics as political order derived from political revolution as the equation below.

$$
\begin{aligned}
& \text { initial social structure with simple technology } \stackrel{\text { technological revolution }}{\longrightarrow} \\
& \text { transitional social structure with complex technology } \\
& \text { changed network for the production-distribution of complex technology } \\
& \text { technology driven changed social structure } \stackrel{\text { internal conflict }}{\longrightarrow} \\
& \text { disordered changed social structure } \stackrel{\text { political revolution }}{\longrightarrow} \\
& \text { peaceful changed social structure with pacifying politics as political order }
\end{aligned}
$$

Table 1. Political order, society, and mentality.

\begin{tabular}{cccc}
\hline $\begin{array}{c}\text { political order } \\
\text { component }\end{array}$ & governmental function & $\begin{array}{c}\text { social } \\
\text { component }\end{array}$ & $\begin{array}{c}\text { mental } \\
\text { origin }\end{array}$ \\
\hline state & core organization & $\begin{array}{c}\text { social } \\
\text { conscience }\end{array}$ & social brain \\
imagination & $\begin{array}{c}\text { political identity for social structure larger than the } \\
\text { band social structure }\end{array}$ & $\begin{array}{c}\text { social dream } \\
\text { theory of } \\
\text { mind }\end{array}$ \\
rule & $\begin{array}{c}\text { rules for a good and functional large and complex } \\
\text { government }\end{array}$ & social rule \\
accountability & verifying a good and functional large and complex \\
government & $\begin{array}{c}\text { social } \\
\text { brain }\end{array}$ & $\begin{array}{c}\text { empirical } \\
\text { brain }\end{array}$ \\
\hline & & accountability & bral
\end{tabular}


Therefore, the four technological revolutions (the Upper Paleolithic, Agricultural-Bronze, Iron, and Industrial Revolutions) produce the four changed social structures (linked bands, tribe, mega empire, and modern nation, respectively) whose internal conflicts to be pacified by the four political revolutions (the imaginative, hierarchical, thinking, bottom-up political revolutions, respectively) to form the four politics (the imaginative egalitarianism, decentralized hierarchical tribalism, centralized top-down thinking, and multilateral bottom-up thinking politics, respectively) as in Equation (2) and Figure 1.

band social structure with realistic egalitarianism politics $\stackrel{\text { Upper Paleolithic Revolution }}{\longrightarrow}$ disordered linked band social structure $\stackrel{\text { imaginative political revolution }}{\longrightarrow}$ peaceful linked band with imaginative egalitarianism politics $\stackrel{\text { Agricultural-Bronze Revolution }}{\longrightarrow}$ disordered tribe social structure $\stackrel{\text { hierarchical political revolution }}{\longrightarrow}$ peaceful tribe social structure with decentralized hierarchical tribalism politics $\stackrel{\text { Iron Revolution }}{\longrightarrow}$ disordered mega empire social structure $\stackrel{\text { thinking political revolution }}{\longrightarrow}$ peaceful mega empire social structure with centralized top-down thinking politics $\stackrel{\text { Industrial Revolution }}{\longrightarrow}$ disordered modern nation social structure $\stackrel{\text { bottom-up political revolution }}{\longrightarrow}$ peaceful modern nation social structure with multilateral bottom-up thinking politics

Section 2 describes the mental origins of political order. Section 3 deals with realistic egalitarianism politics, imaginative egalitarianism politics, and decentralized hierarchical tribalism politics. Section 4 explains centralized top-down thinking politics. Section 5 describes multilateral bottom-up thinking politics.

\section{The Mental Origins of Political Order}

The paper proposes that the mental origins of the generalized four-component structure of political order consisting of state, imagination, rule, and accountability are the social brain, the theory of mind, the rational brain with priories, and the empirical brain without priories, respectively.

\subsection{The Social Brain: State}

The social brain is used in interacting with other people, planning complex cognitive behavior, personality expression, decision making, and moderating social behavior. The social brain includes amygdala, orbital frontal cortex, temporal

\begin{tabular}{|c|c|c|c|c|c|c|c|c|}
\hline $\begin{array}{l}\text { band social } \\
\text { structure with }\end{array}$ & & $\begin{array}{l}\text { linked band } \\
\text { social structure }\end{array}$ & & $\begin{array}{l}\text { tribe social } \\
\text { structure with }\end{array}$ & & $\begin{array}{l}\text { mega empire } \\
\text { structure with }\end{array}$ & & $\begin{array}{l}\text { modern nation } \\
\text { social structure } \\
\text { with }\end{array}$ \\
\hline $\begin{array}{l}\text { politics } \\
\text { politarianism } \\
\text { latic }\end{array}$ & $\begin{array}{l}\text { Upper } \\
\text { Paleolithic } \\
\text { Revolution and } \\
\text { Imaginative } \\
\text { Political } \\
\text { Revolution }\end{array}$ & $\begin{array}{l}\text { imaginative } \\
\text { egalitarianism } \\
\text { politics }\end{array}$ & $\begin{array}{l}\text { Agricultural- } \\
\text { Bronze } \\
\text { Revolution and } \\
\text { Hierarchical } \\
\text { Political } \\
\text { Revolution }\end{array}$ & $\begin{array}{l}\text { hierarchical } \\
\text { tribalism } \\
\text { politics }\end{array}$ & $\begin{array}{l}\text { Iron Revolution } \\
\text { and Thinking } \\
\text { Political } \\
\text { Revolution }\end{array}$ & $\begin{array}{l}\text { down thinking } \\
\text { politics }\end{array}$ & $\begin{array}{l}\text { Industrial } \\
\text { Revolution and } \\
\text { Bottom-up } \\
\text { Political } \\
\text { Revolution }\end{array}$ & $\begin{array}{l}\text { multilateral } \\
\text { bottom-up } \\
\text { thinking politics }\end{array}$ \\
\hline
\end{tabular}

Figure 1. The evolution of political order. 
cortex, medial prefrontal cortex, and mirror system as its major components [4]. After lesions to the amygdala, monkeys become socially isolated. The amygdala attaches emotional value to faces, enabling us to recognize expressions such as fear and trustworthiness. Lesions to orbital frontal cortex can also alter social behavior. Neurons in the superior temporal sulcus respond to aspects of faces such as expression and gaze direction. The medial prefrontal cortex is consistently activated when people think about mental states to represent someone else's representation of our own mental state. The mirror system in the brain arises from the observation that the same brain areas are activated when we observe another person experiencing an emotion as when we experience the same emotion ourselves.

The social brain contains instinctive relations to form the default social structure. All social animals have instinctive relations to form the default social structures without training or with little training. The human social brain [3] consists of sociality for instinctive intragroup relations and worldview for instinctive intergroup relations. In the human social brain, sociality for intragroup relations consists of collectivistic, individualistic, interdependent, and generativity relations. Collectivistic relation benefits vulnerable children against neglect by forming kinship group [3] [5] whose relations depend on commitment to a social group rather than reciprocal benefit of individuals. The origin of collectivistic sociality is the social group of caregivers and vulnerable children. The neurotransmitter to promote kin relations in collectivistic sociality is oxytocin, so people feel good when they are with their kin.

Individualistic relation benefits vulnerable individuals against predation by forming an alliance group [6] [7] [8] whose relations depend on reciprocal benefit of individuals rather than commitment to a social group. The base of individualistic sociality is extensive and complex socialization. For primates, the brain size for individualistic sociality is proportional to the group size and the complexity of socialization. The neurotransmitter to promote alliance in individualistic sociality is endorphins, so people feel good when they have friends.

Interdependent relation benefits vulnerable specialists against handicaps by forming a specialist group from specialists whose relations dependent on existential division of labor [9] [10]. The early hominins formed the interdependent specialist groups consisting of the forest group of homemaker-forager for women and children and the woodland group of explorer-forager for men in the mixed forest-woodland habitat. The handicap was the feet which were still suitable for climbing trees, and not suitable to walk long distance and run fast on the ground especially for pregnant women and small children in woodland area. Later, the division of labor became gatherer-hunter in open savanna habitat. Generativity relation benefits future generations by forming multiple-generation group whose relations depend on legacy [11] [12] [13] [14]. Unlike great apes, infertile women have a long life after menopause allows multiple generations to live together. The caring of infertile women after menopause for their grand- 
children and great-grandchildren is the base of legacy. Therefore, the four sociality relations are collectivistic relation from kin-friends to benefit vulnerable children through commitment, individualistic relation from allies to benefit vulnerable individuals through reciprocity, interdependent relation from specialists to benefit vulnerable specialists through division of labor, and generativity relation from multiple generations to benefit vulnerable future generations through legacy as in Table 2. These instinctive intragroup relations produce the default social structure with kin group, alliance group, division of labor, and generational assistance.

In the social brain, worldview is for intergroup relations based on ingroup and outgroup. In ingroup, individuals have similar interests and outlooks, and produce the feeling of connection among them [15]. Individuals in outgroup outside the boundary of one's own group are different in interests and outlook, and produce the feeling of zero-sum competition toward outgroup. The proper behavior as morality toward ingroup is cooperation, whereas the proper behavior toward outgroup is zero-sum competition [16]. Such ingroup-outgroup boundary instinct appears even in infants at few months old [17]. Worldview relations include territorial relation for ingroup-outgroup intergroup with a clear boundary between ingroup and outgroup, competitive relation for outgroup-like intergroup without a clear boundary between ingroup and outgroup, and cooperative relation for ingroup-like intergroup without clear boundary between ingroup and outgroup as shown in Table 3. These instinctive intergroup relations produce the default social structure with respect to boundary. For competitive worldview, there are win and loss in competition, and for cooperative worldview, there are fulfillment and nonfulfillment of role in cooperation

\subsection{Theory of Mind: Imagination}

Political imagination is the imagination about an imaginary world which has its own mind. The imaginary world includes imaginary common guardian supernatural

Table 2. Sociality for intragroup relations.

\begin{tabular}{cccc}
\hline Intragroup Relation & Intragroup & Beneficiaries & Principle \\
\hline collectivistic & kin-friends & vulnerable children & commitment \\
individualistic & allies & vulnerable individuals & reciprocity \\
interdependent & specialists & vulnerable specialists & division of labor \\
generativity & multiple generations & vulnerable future generations & legacy \\
\hline
\end{tabular}

Table 3. Worldview for intergroup relations.

\begin{tabular}{ccc}
\hline Intergroup Relation & Boundary & Intergroup \\
\hline territorial & clear & ingroup-outgroup intergroup \\
competitive & unclear & outgroup-like intergroup \\
cooperative & unclear & ingroup-like intergroup \\
\hline
\end{tabular}


for a group of people, imaginary common ancestors, and imaginary arbitrary geographic area. Theistic imagination is the imagination about supernatural which has its own mind. Political imagination and theistic imagination are interchangeable. Imagination is based on theory of mind that recognizes (imagines) that the others exist to think for themselves, so it relates to imagination. According to a PET study, theory of mind activates the medial prefrontal node to handle the mental state of the self, the superior temporal sulcus to detect the behavior of other animals and analyzes the goals and outcomes of this behavior, and the inferior frontal region to maintain representations of actions and goals [18]. According to Kapogiannis and Deshpande in the functional MRI study of the brains of both self-declared religious and non-religious individuals, individuals with stronger theory of mind activity were found to be more religious [19]. Thinking about God activates brain regions associated with theory of mind [20]. Autistic individuals with problems in imaginative capacities and pretend plays are incapable of theory of mind [21] [22] [23]. Autism with the deficits in theory of mind is linked to lower belief in God [24]. Robust religion is unique to humans, because robust theory of mind is unique to humans [25]. According to Maurice Bloch [26], the first widespread human religion was derived from the imagination to produce imaginary female figurines and imaginary cave paintings to helps them to survive under existential pressure at the time of the Upper Paleolithic Revolution [27].

As shown in the previous paper [24], theory of mind was not evolved originally to accommodate religious behaviors. Theory of mind was evolved originally to accommodate interdependent division of labor between the forest specialist group (women and children) and the woodland specialist group (men) in early hominins who lived the mixed forest-woodland habitat. To complement each other's work without interfering each other's work, one specialist group had to recognize (imagine) that the other specialist group existed to think for themselves and to do different works. The result was theory of mind which is to recognize (imagine) that the others exist to think for themselves. (The forest-woodland groups became the hunter-gatherer groups for the Homo species in the savanna habitat.) Under normal condition, specialists in division of labor were real. Since theory of mind is closely related to imagination, humans under existential pressure invented imaginary specialists as imaginary agents who existed to think for themselves and to do different work in imaginary division of labor to enhance survival chance, resulting in the religious relief of stress and anxiety to enhance the survival chance of individuals [28]. Under existential pressure, such political and theistic imagination can also be the reinforcement of social bonds to enhance the survival chance of social group [29] [30].

\subsection{The Rational Brain and the Empirical Brain: Rule and Accountability}

Rationalism maintains that some human knowledge is gained through a priori (prior to experience) or innate idea as distinct from sense experience. Empiric- 
ism maintains that human knowledge comes from experiences gathered through the five senses. According to empiricists, our learning is based on our observation-experience. Empiricism is an important part of the scientific method for verification because theories and hypotheses must be observed and tested to be considered accurate. Rationalism and empiricism are the direct opposite of each other. Rationalism is the belief in innate ideas, reason, and deduction, while empiricism is the belief in sense perception, induction, and that there are no innate ideas. Both rationalism and empiricism are derived from the thinking brain with deliberation, precision, and reason. The rational brain with priories is for rule, while the empirical brain without priories is for accountability (verification).

The political brain includes the emotional-instinctive brain, the subjective thinking brain, and the objective thinking brain [31]. The emotional-instinctive brain locates in the subcortex and the limbic regions, and the neurotransmitters include endorphins for individualistic sociality and oxytocin for collectivistic sociality. Emotion and instinct are blunt and black-and-white reactions without discerning. They occur extremely rapidly before conscious thoughts. The subjective thinking brain uses reasoning to defend the view derived from instinct and emotion against the opposite point of view. The subjective thinking brain locates in the orbital frontal cortex for the processing of emotions, the anterior cingulate for conflict resolution, the posterior cingulate for making judgments about moral accountability, and the ventral striatum for reward and pleasure. The neurotransmitters are glutamine and dopamine. The objective thinking brain locates in the dorsolateral prefrontal cortex for objective reasoning and analysis without bias. The neurotransmitter is glutamine. Political brain is described in Table 4. Objective thinking plays a limited role in political decisions. According to Drew Westen [31], only between 0.5 and 3 percent of the most important political decisions utilize objective thinking. Ideally, the rational brain for rule and the empirical brain for accountability are derived from objective thinking brain.

\section{Realistic Egalitarianism Politics, Imaginative Egalitarianism Politics, and Decentralized Hierarchical Tribalism Politics}

This paper posits that in the evolution of political order, the main function of political order is to pacify changed social structure derived from technological revolution. Therefore, the four technological revolutions (the Upper Paleolithic,

Table 4. Politics Brain.

\begin{tabular}{ccc}
\hline Political brain & Location & Neurotransmitter \\
\hline Emotional-instinctive brain & Subcortex and limbic regions & $\begin{array}{c}\text { Endorphins and } \\
\text { oxytocin }\end{array}$ \\
Subjective thinking brain & $\begin{array}{c}\text { Orbital frontal cortex, anterior cingulate, posterior } \\
\text { cingulate, and ventral striatum }\end{array}$ & $\begin{array}{c}\text { Glutamine and } \\
\text { dopamine } \\
\text { Objective thinking brain }\end{array}$ \\
\hline
\end{tabular}


Agricultural-Bronze, Iron, and Industrial Revolutions) produce the four changed social structures (linked bands, tribe, mega empire, and modern nation, respectively) whose internal conflicts to be pacified by the four political revolutions (the imaginative, hierarchical, thinking, bottom-up political revolutions, respectively) to form the four politics (the imaginative egalitarianism, decentralized hierarchical tribalism, centralized top-down thinking, and multilateral bottom-up thinking politics, respectively). This section deals with realistic egalitarianism politics, imaginative egalitarianism politics, and decentralized hierarchical tribalism politics.

\subsection{Realistic Egalitarianism Politics: Band Social Structure}

The evolution of political order starts from realistic egalitarianism politics with the band social structure around 200,000 years ago to the beginning of the Upper Paleolithic Period about 40,000 years ago. A band society of hunter-gatherers is the simplest form of human society. A band generally consists of a small group ranging from 30 to 50 people [32]. Their power structure is egalitarian. The cooperative behaviors in a band, however, are not entirely derived from kin relation. Hill and colleagues found that the bands in their dataset are not composed mainly of close kin [33]. Bands are mainly composed of individuals either distantly related by kinship and/or marriage or unrelated altogether. In their sample of 32 societies, primary kin generally make up less than $10 \%$ of a residential band. They found that hunter-gatherers display a unique social structure where 1) either sex may disperse or remain in their natal group, 2) adult brothers and sisters often co-reside, and 3) most individuals in residential groups are genetically unrelated. Therefore, in terms of the social brain, individualistic sociality to form alliance group is much more important than collectivistic sociality to form kinship group for the human band social structure. Instinctive interdependent relation provided the social structure for division of labor in terms of hunters and gatherers. Instinctive generativity provided the social structure of infertile grandparents as caregivers. The worldview was territorial worldview with a clear boundary. The human social brain can manage the social group size of about 150 people (Dunbar's Number) [34], so people in a band from 30 to 50 people can deal with several bands at the same time.

\subsection{Imaginative Egalitarianism Politics: Linked Band Social Structure}

The Upper Paleolithic Revolution for complex tools occurred in the Upper Paleolithic Period between 10,000 and 40,000 years ago before the Agricultural Revolution. Similar to the Industrial and Agricultural Revolutions, the Upper Paleolithic Revolution during the Upper Paleolithic period represents a short time span when numerous inventions appeared and cultural changes occurred. The revolution comprised new religions, technologies, hunting techniques, human burials, and artistic work [35]. 
During the Upper Paleolithic Period, a number of sudden temperature drops reduced significantly the area for forest in Europe and Asia. The Neanderthal became extinct during this period. The reduction of forest reduced the food supply, usable timber, and other non-food materials. The reduction of the number of trees forced humans to look for alternatives to wood to make tools. The new tools used bone, antler, and ivory. During this time, humans also learned to apply heat to clay objects in order to harden them. Humans also made advanced tools including fish hooks, rope, oil lamps, and eyed needles.

The bands with simple tools were converted to the transitional bands with complex tools by the Upper Paleolithic Revolution for complex tools. No single or several bands within 150 people (Dunbar's Number) could make all complex tools to survive. Different bands had different specialties for tools. To obtain some useful tools, humans had to deal with total strangers in faraway places. The bands started the network for the production-distribution for complex tools. At the same time, humans also developed complex arts and decorations from shells, animal teeth, and ivory which could be very useful in trading complex tools. The network for the production-distribution resulted in technology-driven linked egalitarian bands social structure with the population much more than 150 people (Dunbar's Number). The instinctive human social brain cannot manage a social group with much more than 150 people. The population in the technology driven linked band social structure was too large for the instinctive human social brain. The small social group size instinct became the cause for the internal conflict, resulting in disordered technology-driven linked band social structure.

At the same time during the harsh Upper Paleolithic Period, women were under intense existential pressure to have successful fertility, while men were under intense existential to have strong vitality. The imaginary female figurines and cave paintings appeared during the period. The imaginary exaggerated and distorted female figurines were miniature sculptures of well-rounded female nudes with an overemphasis of the fleshy parts of the body (buttocks, stomach and chest). The sexual accent on the female breasts and the posterior are assumed by many to connote signs of fertility. According to Alan F. Dixson and Barnaby J. Dixson, these female figurines symbolized and brought the hope for a well-nourished and fertile community to change the fate of facing grim winters and scarce food supply [36]. The imaginary female figurines provided the power to have successful fertility by enhancing the comforter countermeasure in the mental immune system against hardship. In the imaginary cave paints, the animals were mystic large strong animals or mystic animals with horns that symbolized maturation and strength. According to David Lewis-Williams [37], the imaginary cave paintings involved hallucinatory or trance states by drugs or repetitive rhyme. The mystic animal pictures were conceived during the trance states. These cave paintings symbolized and brought the hope for a vital and powerful community to change the fate of facing grim winters and scarce food supply. The imaginary cave paintings provided the power to have strong vitality 
by enhancing the comforter countermeasure in the mental immune system against hardship. The magic in female figurines and cave paintings to bring humans hopes was driven from theistic imagination based theistic theory of mind that imagines female figurines and cave paintings had their own minds and powers to help humans to overcome such harsh conditions.

During the Upper Paleolithic Period, there was the increased sharing of the female figurines and the cave paintings among different bands. The enormous distribution of these female figurines implied a ritualistic exchange system with the figurines playing a central role in intergroup relations [38] to pacify the technological driven linked bands social structure. The result was the imaginative political revolution to produce imaginative egalitarianism politics. Therefore, the social structure change to the linked band social structure derived from the Upper Paleolithic Revolution for complex tools had the internal conflict due to small social instinct which was pacified by the imaginative political revolution to produce peaceful the linked band social structure with imaginative egalitarianism politics as the equation below.

initial social structure realistic egalitarianism politics and simple tools $\stackrel{\text { Upper Paleolithic Revolution }}{\longrightarrow}$ transitional band social structure with complex tools

changed infrastructure for the production-distribution of complex tools

technology driven linked band social structure $\stackrel{\text { small social group instinct }}{\longrightarrow}$

disordered linked band social structure $\stackrel{\text { imaginative political revolution }}{\longrightarrow}$

peaceful linked band social structure with imaginative egalitarianism politics

Imaginative egalitarianism politics with the shared theistic imagination became necessary and permanent part of stable linked band social structure. Without religious imagination [39], the Neanderthal became extinct during this period. In terms of the components in political order, imaginative egalitarianism politics has both state and imagination. The actual rulers were people in imaginative egalitarianism politics. In imaginative egalitarianism politics, the supernatural was the immanent supernatural that appeared everywhere as a part of all objects in the world. Religion included animism, afterlife, and shamanism. Female figurines and cave paintings are about animism. Peoples, Duda, and Marlowe found the oldest trait of religion, present in the most recent common ancestor of present-day hunter-gatherers, was animism. Belief in an afterlife emerged, followed by shamanism. Ancestor worship and high gods who are active after the Upper Paleolithic Period were absent in early hunter-gatherer, suggesting a deep history for the egalitarian nature of hunter-gatherer societies [40].

\subsection{Decentralized Hierarchical Tribalism Politics: Tribe Social Structure}

The Agricultural Revolution (Neolithic Revolution) started at different times at different parts of the world. The earliest started about 12,000 years ago in 
Southwestern Asia. The causes of the Agricultural Revolution may have varied from region to region. The Bronze Age also started at different times at different parts of the world. The earliest started about 5500 years ago in Southwestern Asia. The Levant saw the earliest developments of the Neolithic Revolution from around 12,000 years ago, followed by sites in the wider Fertile Crescent around 11,000 years ago. India 11,000 year ago, the Yangtze and Yellow River basins 9000 years ago, and Egypt around 6500 years ago. The Bronze Age ended about 3000 years ago when the Iron Age started. As a result, the Agricultural-Bronze Revolution is between 12,000 and 3000 year ago.

The Agricultural Revolution through the domestication of plants and animals marked the transition in human history from small nomadic bands of hunter-gatherers to larger agricultural settlements and early civilization. The Bronze Age brought about proto-writing and other early features of urban civilization. Agricultural-bronze technology is much more complex than hunting-gathering technology, resulting in changed network for the production-distribution of agriculture-bronze. Such changed network for the production-distribution of agriculture-bronze brought about agriculture-bronze technology driven changed social structures such as small tribes and city states. The complex agricultural technology with a large social group working together required the coordination and technological knowledge of few people, resulting in hierarchical social structure. Such group of few people controlled many people who did not have the power of coordination and technological knowledge. Egalitarianism from egalitarian band theism became the cause for the internal conflict of small tribes and city states, resulting in disordered changed social structure. The disordered social structure was pacified by hierarchical tribalism politics, including ancestor worship and high gods. Ancestor worship is defined as belief that the spirits of ancestors remain active in another realm where they may influence the living and can be influenced by the living [41]. Ancestor worship allowed the hierarchical social structure to be inherited. "High gods" is defined as single, all-powerful creator deities who may be active in human affairs and supportive of human morality [42]. Ancestor worship and high gods appointed hierarchical social structures. Each tribe had one dominant ancestor or high god.

A single tribe was in the agricultural-bronze technology driven changed social structure containing many other tribes. The result was the decentralized union of hierarchical tribes. The union could be the alliance of tribes or a mid-size overlord empire with a number of client tribes. At that time, no single tribe was strong enough from available technologies to centralize the powers in the union. The lack of centralized power was manifested in decentralized hierarchical tribalism politics with polytheism. Therefore, the social structure change to the tribe social structure derived from the Agricultural-Bronze Revolution had the internal conflict due to egalitarianism which was pacified by the hierarchical political revolution to produce the peaceful tribe social structure with decentralized hierarchical tribalism politics in the equation below. 


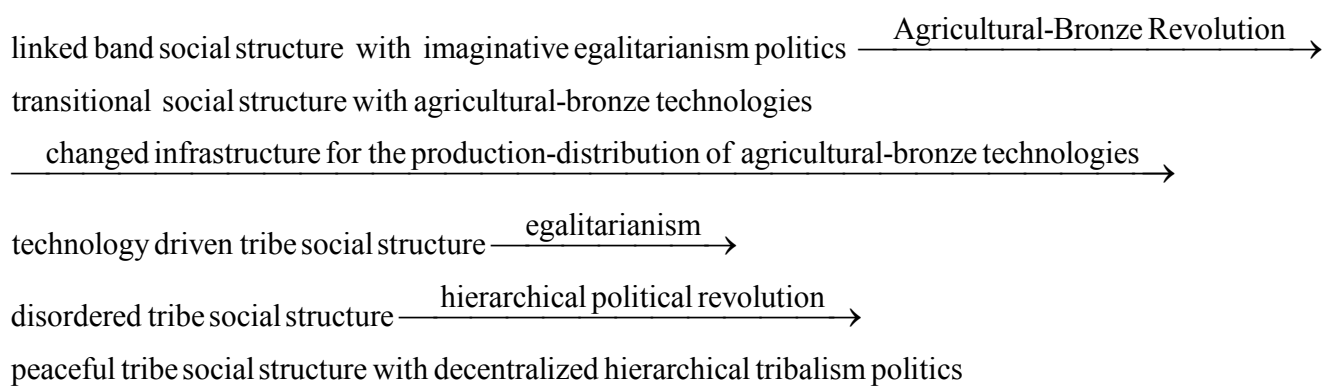

The actual rulers were local tribal chiefs. Each tribe had its own deity under the chief deity, resulting in polytheism. In polytheism, the chief deity was typically remote, and people worshiped their local deities. One typical example of polytheism is the polytheism in Canaan. Canaan, an ancient region between the River Jordan and the Mediterranean, located in the Levant region of present-day Lebanon, Syria, Jordan, and Israel. The chief deity was El. During the Bronze Age and the early Iron Age, each tribe had its own local tribal deity under El as el in the word of Israel [43]. Israel and Judah shared Yahweh as their tribal god. The various tribal gods were more or less equal. Because of the intermarriages and alliance among these tribes, each tribe had altars for the national gods of neighboring tribes. According to archeological evidence [44], during this time, idols represented other religions were found commonly in Jewish homes. On the whole, Mark S. Smith shows how Israelite polytheism was a feature of Israelite religion until the seventh and sixth centuries [45]. In terms of political order, decentralized hierarchical tribalism politics has state and imagination components.

\section{Centralized Top-Down Thinking Politics: Mega Empire Social Structure}

The Iron Age (the Iron Revolution) started between 1200 BC and 600 BC, depending on the region. Iron is tougher and lighter than bronze and was used to make much better sharp objects like spears, swords, and sharp tools than bronze. The source for iron was much more abundant than bronze. Through the Iron Revolution, the decentralized union of hierarchical states with agricultural-bronze technologies was converted to the transitional social structure with iron technology. The iron technology produced changed network of the production-distribution for iron technology with the world's urban population nearly doubled in the years 600 to 450 BC [46]. The changed network led to the iron technology-driven changed social structure which was a mega centralized empire. The state with iron technology was strong enough with enough destructive power of iron weapons to centralize powers in the transformation of decentralized union of hierarchical states into a mega centralized empire. The earliest proto-mega centralized empire is the Hittite Empire based on the advantages entailed by its high advancement on ironworking at the time [47]. The Hittite Empire was not very large, and did not last long. The earliest mega centralized 
empires were the neo-Assyrian empire (934-609 BC) and the neo-Babylonian empire (612-539 BC). In some regions, such as China, the late bronze period and the early iron period were overlapped, so mega empires were formed in the late bronze period, and completely solidified in the iron period.

Under a centralized mega empire, different cultures under different standards and forms were in conflict, resulting in the disordered mega centralized empire. Such conflicting cultures simply overwhelmed the emotional-instinctive political brain, resulting in the rises of the thinkers with the thinking political brains. They found the rational brain for rule and the empirical brain for accountability (verification) to establish a viable mega centralized empire. Few people were in control of technology, so the mega empires were top-down for the elite. Rule and accountability were mostly controlled by the elite. The top-down thinkers who provided the thinking ruling methods for emperors became an important part of ruling class. The result is centralized top-down thinking politics. In terms of the components of political order, centralized top-down thinking politics has state, imagination, rule, and accountability. Rule and accountability from the thinking brain modify state and imagination from the emotional-instinctive brain. Therefore, the social structure change to the mega empire social structure derived from the Iron Revolution had the internal conflict due to conflicting cultures which were pacified by the thinking political revolution to produce the peaceful mega empire social structure with centralized top-down thinking politics in the equation below.

the tribe social structure with decentralized hierarchical tribalism politics $\stackrel{\text { Iron Revolution }}{\longrightarrow}$ transitional social structure with iron technology

changed infrastructure for the production-distribution of iron technology technology driven mega empire $\stackrel{\text { conflicting cultures }}{\longrightarrow}$

disordered mega empire social structure $\stackrel{\text { thinking political revolution }}{\longrightarrow}$

peaceful mega empire social structure with top-down thinking politics

The internal political power structure of a mega empire was much more diffused than the internal political power structure of a tribe, simply because a single royal family in a mega empire could not rule such large country. The actual ruling class of a mega empire includes upper class consisting of royal family, wealthy landowners, wealthy manufacturers, and wealthy traders. As a result, the ruling class of a mega empire consists of top-down thinkers and upper-class people. Most people were lower class people. They were illiterate and uneducated. They were productive, but they were controlled politically by the educated upper class people.

For the mega empire social structure, a powerful emperor could eliminate boundary easily, so boundary was not clear, resulting in competitive worldview or cooperative worldview without a clear boundary. For competitive worldview to have winners and losers, most people are competitors. In competitive 
worldview, to rule competitors, force is necessary for a government to settle disputes among competitors, and to be accountable among competitors, a ruler has to be a winner among competitors. As a result, in competitive centralized top-down thinking politics with the thinking brain and competitive worldview, the rational rule of competition among competitors is the orderly rule by law, and the empirical accountability of competition among competitors is the orderly accountability by election. A government has to use force to enforce the orderly rule of law among competitors, and a ruling government has to be a winner in the orderly accountability by election among competitors. Under the rule by law among competitors in the top-down politics, everyone did not have an equal chance to compete in legal court. Under the accountability by election among competitors in the top-down politics, everyone did not have equal chance to compete in the accountability by election.

For cooperative worldview, most people are kin-friends. In cooperative worldview, to rule kin-friends, morality is necessary for a government to establish cooperative relations among kin-friends, and to be accountable among kin-friends, a ruler has to be a professional to manage the group of kin-friends. As a result, in cooperative centralized top-down thinking politics with the thinking brain and cooperative worldview, the rational rule of cooperation among kin-friends is the rule by relation, and the empirical accountability of cooperation among kin-friends is the accountability by professional qualification. A government has to use morality to establish the moral rule of relation among kin-friends, and a ruling government has to be verified by professional qualification among kin-friends. Under the rule by relation among kin-friends in the top-down politics, everyone did not have an equal chance to be related (included) in society. Under the accountability by professional qualification among kin-friends in the top-down politics, everyone did not have an equal chance to be included in the accountability by professional qualification.

In the West originated from Greece and Middle East, competitive worldview dominated cooperative worldview, and in the East originated from India and China, cooperative worldview dominated competitive worldview. Instinctive worldview affects perceptions. For cooperative worldview, the perception that focuses in cooperative ingroup is "relationship perception" to build relationship among members in ingroup, while for competitive worldview, the perception that focuses in competitive outgroup is "identity perception" to differentiate the identity of outgroup from the identity of ingroup. With instinctive cooperative relationship perception from cooperative worldview, the Easterners see a world of continuous and connected objects with relationships, while with instinctive discrete identity perception from competitive worldview, the Westerners see a world of discrete and unconnected objects in categories based on similarity and difference. The Westerners pay attention to the focal object separated from its surrounding based on discrete perception, while the Easterners attend more broadly to the overall surroundings and to the relations between the object and the field [48] [49]. Therefore, in the competitive West originated from Greece 
and Middle East, the rational rule of competition among competitors was the rule by law, and the empirical accountability of competition among competitors was the accountability by election. In the cooperative East originated from India and China, the rational rule of cooperation among kin-friends was the rule by relation, and the empirical accountability of cooperation among kin-friends was the accountability by professional qualification.

\subsection{The Rule and the Accountability in China}

In China, cooperative worldview is represented by Confucianism, and competitive worldview is represented by Legalism. Confucius (551-479 BC) was born in effectively independent state of Lu notionally controlled by the kings of Zhou during the Spring and Autumn period (771-476 BC). The states were at war with each other, and high government officers within a state were at war with each other. During this Hundred Schools of Thought era, many schools of philosophy offered rulers advice to govern the states. Confucius travelled to many states to offer advice. To Confucianism, the explicit expression of the rule by relation is $l i$ that is the ritual propriety to express the different manners toward the different relations, in particular, the "five relations": ruler and subject, parent and child, husband and wife, elder and younger sibling, and friend and friend. To Confucianism, people are mostly kin-friends. $L i$ is derived from the deliberate thinking brain to control the impulsive emotional-instinctive brain. The difference between civilized society and barbarian society is $l i$. Each relation in $l i$ is supported by different aspects of morality, so each human interaction in manner and in motivation is supported by morality and the thinking brain.

The relations in Confucianism are derived from the instinctive relations from the social brain, including sociality for intragroup relations (collectivistic sociality, individualistic sociality, interdependent sociality, and generativity sociality) and worldview for intergroup relations (cooperative worldview, competitive worldview, and territorial worldview). Collectivistic sociality is for kin group whose principle is commitment. In Confucian morality for kin group, parent-child relation involves care and teaching from parent and filial piety from child. Husband-wife and elder-younger siblings show respect, responsibility, and loyalty for each other. Individualistic sociality is for alliance group whose principle is reciprocity. The Confucian morality for alliance group involves ren (benevolence), yi (uprightness), xin (faithfulness), shu (reciprocity), and li (propriety). Interdependent sociality is for specialist group whose principle is division of labor. The Confucian morality for division of labor involves the specific responsibility of each specific role. Duke Jing of Qi asked Confucius about government. Confucius replied: "Let the ruler be a ruler, minister be a minister, father be a father, son be a son." (Analects 12:11) Generativity sociality is for multiple-generation group whose principle is legacy. The Confucian morality for generativity is ancestor veneration to keep the memory of many generations. For intergroup relations (worldviews), Confucianism encourages cooperative worldview. Cooperative worldview is expressed as harmony. "In practicing the rules of pro- 
priety, it is harmony that is prized." (Analects 1:12) Harmony is prized among the differences. Confucius said: "Noble persons seek harmony but not sameness. Petty persons seek sameness but not harmony." (Analects 13:23).

Han Feizi (280-233 BC) was one of China's most prominent legalists. One of Han's main concerns was how to prevent uprisings and treason, and how to govern in such a way that all subjects will obey the ruler. To Legalism, people are mostly competitors fighting against one another. $L i$ in Confucianism is equivalent to $\mathrm{fa}$ (law) in Legalism. $\mathrm{Fa}$ is derived from the deliberate thinking brain to control the impulsive emotional-instinctive brain. The legalists rely on the force of sanctions to obtain obedience to and compliance with the law, and therefore they stress government by fa or decree, as opposed to the Confucian emphasis on government by $l i$. The legalists insist on complete equality before fa, as opposed to the Confucian acknowledgment of the inequality of people. The legalists enforce objective and unvarying rules of conduct, in contrast to the Confucian acceptance of different rules for different relations and positions.

In China historically, a ruler could be a professional ruler or a winner ruler. The first emperor in the decentralized China is Yu the Great (2123-2025 BC) as the founder of Xia Dynasty (2070-1600 BC). Yu the Great was a professional engineer who became a professional ruler because he introduced flood control benefiting people. Yu successfully devised a system of flood controls that relieved flood water, provided irrigation, and dredged riverbed. The tradition of professional rulers became an important part of Chinese traditions. The concept of professional ruler was formalized as the mandate of heaven. Heaven gives the mandate to a ruler who is professionally qualified to be a ruler. Therefore, a ruler is accountable for professional qualification in terms of education, experience, capability, and ethics. In fact, all princes in Chou Dynasty had to be educated and trained professionally to be rulers. Because of this tradition, in Chinese, morally noble and broad-minded people are called "sons of king”. Confucianism accepts the accountability by professional qualification for a ruler.

On the other hand, the Legalists like Han Feizi believed only in strong army to be the ultimate winner ruler. A winner ruler was accountable for winning war. The legalists did not develop the concept of empirical accountability by winning the election. Qin Shihuang (260-210 BC), the emperor who unified China for the first time in $221 \mathrm{BC}$, was aided by the Legalists in establishing his new state with a strict legal system, an extensive government bureaucracy, a strong military force, and a comprehensive taxation system. Qin Shihuang attempted to destroy all other schools of philosophy. The Qin dynasty ended quickly after his death. The Han dynasty (206 BC-220 AD) after the Qin Dynasty combined Confucianism and Legalism. In various dynasties, China maintained various legal systems, but in practice, $l i$ from Confucianism dominated fa from Legalism. The rule by law had to be adjusted by the rule by relation. All high administrators in government had to be professionally qualified through the national examination system and the national promotion system. All princes had to be educated and 
trained to be professional rulers. There was no competitive election system, because such partisan competition was considered immoral in the cooperative society. The Chinese word for party is dang which has a bad connotation as a group of factional-minded people. Both Legalism and Confucianism endorsed the concept of absolute monarchy. They never questioned the legitimacy of the imperial idea. Therefore, they basically followed top-down politics.

\subsection{The Rule and the Accountability in India}

In India, the rule by relation was the Varna (caste) system based on division of labor in terms of division by professions (Brahmin Varna for priests and thinkers, Kshatriya Varna for rulers and warriors, Vaishya Varna for merchants and skill workers, and Shudra Varna for labors). Human interdependent relation for division of labor is instinctive as the prehistorical hunter-gatherer society was divided into hunter profession and gatherer profession. In the Hindu Vedas, the Varna is actually not equivalent to caste which is a Western word. "Varna" means one that is adopted by choice. "Caste" means one that is adopted by birth. In Vedic culture, everyone is considered to be born as Shudra. Through education, one becomes a Brahmin, Kshatriya or Vaishya. This completion of education is considered to be a second birth to obtain the status of "Dwija" (twice-born) for a Brahmin, Kshatriya or Vaishya. However, due to frequent foreign invasions, the Varna system became more rigid to protect the Varna system from the invaders. (Militarily, Indian cooperative worldview was weaker than foreign invaders' competitive worldview.) The Varna system produced naturally the accountability by professional qualification. In the Varna system, everyone was not equal as the Varna system followed the top-down politics. In China and India, the rule by relation and the accountability by professional qualification worked well in spite of frequent foreign invasions, as they dominated the world economy before the Industrial Revolution.

\subsection{The Rule and the Accountability in the West}

In the Middle East, monotheism for centralized top-down thinking politics centralized polytheism for decentralized tribalism politics. Monotheism includes Zoroastrianism, Judaism, Christianity, and Islam. Zoroastrians believe in one God, called Ahura Mazda (meaning "Wise Lord"). He is compassionate, just, and is the creator of the universe. Zoroaster placed less emphasis on ritual worship than on the central ethics of 'Good Words, Good Thoughts and Good Deeds'. The creator became the simulated mega benevolent emperor.

The failure of polytheism in as the alliance of deities for the alliance of states led to the development of personal monotheism in Israel and Judah. In 722 BC, Israel was defeated by the mega Assyria Empire which was strong enough to defeat various states with enormously destructive army and iron weapons. Israelites witnessed the failure of polytheism with the alliance of deities for the alliance of states. No alliance could defeat the mega Assyria Empire who looked 
down at all local deities. To some Israelites, the only salvation was to convert the local deity of Yahweh into the mega universal deity of Yahweh who had the power over all earthly empires. The mega universal deity of Yahweh was the only answer to oppose the mega emperor of the mega Assyrian Empire [50]. The mega universal deity was monotheism. Some of the refugees who fled from Israel to Judah brought with them the Yahweh only monotheism to Judah, and convinced some very influential people to believe in monotheism replacing polytheism. Several kings in Judah became the strong supporters of monotheism. The Jewish prophets who promoted monotheism had to think rationally and imaginatively how local deity Yahweh behaved like monotheistic God. As a result, the Jewish prophets as rational and imaginative thinkers rationalized and imagined that the practice of polytheism by Israelites was the reason for the defeat and suffering of Israelites as the punishment by monotheistic Yahweh. However, Yahweh as the universal deity would not abandon Israel-Judah, and one day Israel-Judah would rise again under monotheistic Yahweh. In this way, Yahweh behaves as monotheistic God to centralized polytheism in decentralized tribalism politics. Christianity with much fewer rules and traditions than Judaism is basically a broaden Judaism appealing to all people, and maintains monotheism to appeal to mega centralized empires. Eventually, the mega centralized Roman Empire adopted Christianity as the state religion. Islam is another personal monotheism suitable for mega centralized empires.

In the West originated from the Middle East and Greece, the top-down rule by law is a method that governments and people in power use to shape the competitive behavior of people as competitors. The top-down rule by law usually has the end goal of psychologically or forcefully persuading people to agree with policy decisions they otherwise would not agree with. The rule by law is derived from the rational brain with deliberation, precision, and reason to control the impulsive emotional-instinctive brain, resulting in rational competition instead of impulsive competition. For example, the 10 commandments in the Bible are as follows.

1) You shall have no other Gods before me

2) You shall not make for yourselves an idol

3) You shall not misuse the name of the LORD your God

4) Remember the Sabbath day by keeping it holy

5) Honor your father and your mother

6) You shall not murder

7) You shall not commit adultery

8) You shall not steal

9) You shall not give false testimony

10) You shall not covet

The first four commandments are for competitive gods. The fifth commandment is for competitive parents and children. The other five commandments are for the competitions for life, love, property, favoritism, and good thing. The Bible also mentions the rule by relation in Matthew 22:37-40, Jesus replied: “Love 
the Lord your God with all your heart and with all your soul and with all your mind.' This is the first and greatest commandment. And the second is like it: 'Love your neighbor as yourself.' All the Law and the Prophets hang on these two commandments." Therefore, according to Jesus, the rule by relation should dominate the rule by law, as Jesus himself transformed the rule by law into the rule by relation through his sacrificial death and resurrection.

Aristotle recognized that the rule by law required the separation of powers, including legislative branch to make the rule by law, the executive branch to enforce the rule by law, and the judicial branch where individual judges base their decisions solely on facts and law of individual cases independently of either the executive or legislative powers. This separation of powers for the rule by law served as a direct model of government for the writers of the American constitution.

The top-down accountability by competitive election involves only the elite competitors at a low percentage of total population. The accountability by election is derived from the empirical brain with deliberation, precision, and reason to control the impulsive emotional-instinctive brain, resulting in the accountability by winning election instead of the accountability by winning the battle. The accountability by election is elite competitive democracy. It was practiced in Athens and Rome. Around $460 \mathrm{BC}$, Athens established the constitution which is called a democracy because it respects the interests not of the minority but of the whole group of elite competitors. When it is a question of settling private disputes, every elite competitor is equal before the law. Elite competitors probably accounted for $10 \%-20 \%$ of the polis population with about 3000 active participants in politics. Of this group, perhaps about 100 wealthiest and most influential elite competitors dominated the political arena both in front of the assembly and behind the scenes in private conspiratorial political meetings and groups. The contemporary critics of democracy pointed out that competitive democracy could be too easily swayed emotionally by a good orator or popular leaders (the demagogues).

Plato's ideal government is a mixed government which combined the tyrannical Persian Empire and the purely democratic city-state of Athens. The Roman Republic (509-27 BC) combined both tyranny and democracy. The Republic was divided into the three basic parts including elected non-hereditary magistrates, a Senate to advise and consent, and popular assemblies. Instead of a king, and to guard against despotism, the Republic chose two consuls as executive magistrates appointed by the popular assembly. The two consuls represented tyranny. The Senate served as an advisory body to the consuls. Throughout most of its existence, the Roman Senate remained the domain of the wealthy. It was the embodiment of oligarchy, a lawmaking body governed by the aristocracy. The democratic part of Roman government was in the form of assemblies, in which the Roman people directly elected executive magistrates. The Roman Republic served as a direct model of government for the writers of the American constitution. 


\section{Multilateral Bottom-Up Thinking Politics: Modern Nation Social Structure}

The Industrial Revolution contains four stages. The first industrial revolution began in Britain in the late $18^{\text {th }}$ century. It was centered on textiles, steam power, and iron. The second industrial revolution was between 1870 and 1914 after the civil war in America. It was centered on steel, railroads, petroleum, chemicals, and electricity. The third industrial revolution as the information revolution began in the 1980s with the proliferation of digital computers, digital record, personal computers, the internet, and information and communications technology. The fourth industrial revolution builds on the third industrial revolution and combines robotics, artificial intelligence, nanotechnology, quantum computing, biotechnology, the Internet of Things (IoT), decentralized consensus, 3D printing, and autonomous vehicles [51]. The fourth industrial revolution allows highly individualized global production-distribution-information.

In the Industrial Revolution, the dramatic increase in productivity lifted most people from the poverty. The Industrial Revolution allows and requires all individuals to be educated. The ubiquitous individual rights from the ubiquitous individual wealth simply overwhelmed the top-down empires. The Industrial Revolution also makes globalization possible, and there is no centralized global politics to unify mega empires or mega nations, so the politics is no longer centralized as in mega empires. As a result, the centralization in mega empire is transformed into multilateralism during the Industrial Revolution. Therefore, the social structure change to the transitional modern nation social structure derived from the Industrial Revolution had the internal conflict due to ubiquitous individual rights which were pacified by the bottom-up political revolution to produce the peaceful modern nation social structure with multilateral bottom-up thinking politics in the equation below.

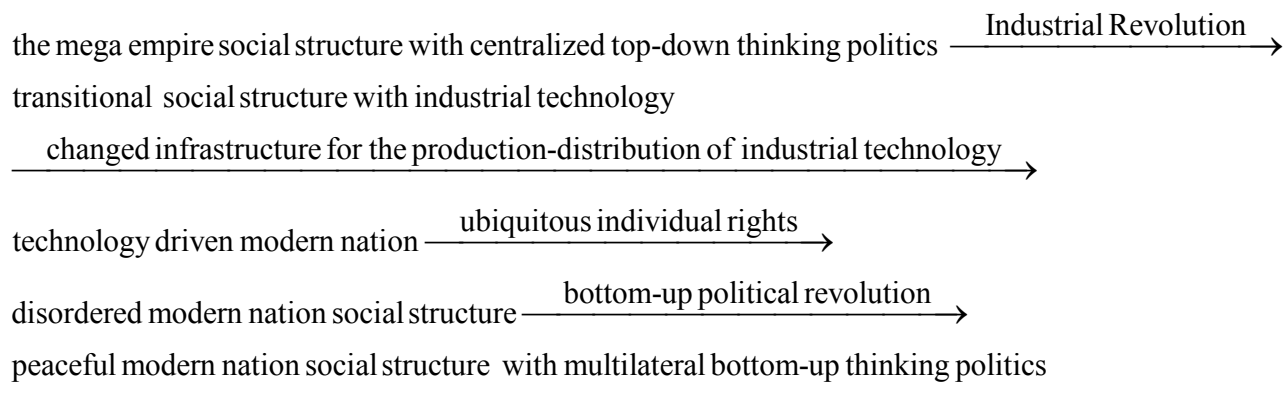

The internal political power structure of a modern nation is much more diffused than the internal political power structure of a mega empire because of ubiquitous individual rights. As a result, the actual ruling class consists of bottom-up thinkers and all people. The bottom-up thinkers during the Industrial Revolution include Abraham Lincoln to promote equal political right for all races and Karl Marx to promote equal political right for all people to become a classless society. Their principles have become the foundations for the democracy for all races and people. The ruling class for the prehistoric band society was 
people in a small social group without using imagination and the thinking brain. The ruling class for the modern nation is also people in a very large social group with imagination and the thinking brain. The class struggle and conflict always exist in human history, but with the high concentration of power due to technology, it was very hard for the lower class to win. The Industrial Revolution requires all people to be literate and educated, resulting in the diffusion of the political power structure of a modern nation.

The modern nations today are divided into the competitive bottom-up thinking politics based on competitive worldview and the cooperative bottom-up thinking politics based on cooperative worldview. For the competitive bottom-up thinking politics, the citizens are competitors, and the liberty to compete among competitors is the goal of the constitution even at the expense of wellbeing. For the cooperative bottom-up thinking politics, the citizens are kin-friends, and to be included in the wellbeing among kin-friends is the goal of the constitution even at the expense of liberty. Under competitive worldview, there are winners and losers among competitors. Under cooperative worldview, there are fulfilled and unfulfilled roles among kin-friends.

\subsection{The Competitive Bottom-Up Thinking Politics}

The principles in the competitive bottom-up thinking politics are the rule of law and the accountability of election bottom-up and equally for everyone. The competitive bottom-up thinking politics is liberal democracy based on liberty. The top-down rule by law is a method that governments and people in power use to shape the competitive behavior of people as competitors. In the bottom-up rule of law, all people, including people in power and people at the lowest level of citizenship, are all equal under the law itself. No one is above the law, and any law that is broken should be equally punished across the board, regardless of status in society or local community. The rule of law is carried out by the Aristotle's separation of powers. As a result, Robert Stein offers the following definition as ideal characteristics of a society governed by the rule of law [52].

1) The law is superior to all members of society, including government officials vested with either executive, legislative, or judicial power.

2) The law is known, stable, and predictable. Laws are applied equally to all persons in like circumstances. Laws are sufficiently defined and government discretion sufficiently limited to ensure the law is applied non-arbitrarily.

3) Members of the society have the right to participate in the creation and refinement of laws that regulate their behaviors.

4) The law is just and protects the human rights and dignity of all members of society. Legal processes are sufficiently robust and accessible to ensure enforcement of these protections by an independent legal profession.

5) Judicial power is exercised independently of either the executive or legislative powers and individual judges base their decisions solely on facts and law of individual cases. 
The rule of law is not strict, because the rule of law is adjusted by the rule of relation in many special cases related to relations. For examples, a person does not need to testify against self, spouse, close relative, and client in lawyer-client relation. Government executives have special privileges to pardon, keep secret from the public, and have executive immunity. Overall, the rule of law dominates the rule of relation.

The bottom-up accountability of election is inclusive competitive liberal democracy for all citizens as competitors, while the top-down accountability by election is elite competitive liberal democracy for elite citizens as elite competitors. Only after the Industrial Revolution, American women were allowed to vote. The Industrial Revolution transformed elite competitive liberal democracy into inclusive competitive liberal democracy. However, the accountability of election in the West is not strict, because it is mixed with the accountability of professional qualification. The accountability of professional qualification began its popularity in Europe in the $19^{\text {th }}$ century to improve the quality of civil service, Europe and America introduced civil service by professional qualification. Since then, the European and American political systems have been a mixed system of accountability of election and the accountability of professional qualification. Different countries have different degrees of the accountability of professional qualification. Overall, the accountability of election dominates the accountability of professional qualification.

\subsection{The Cooperative Bottom-Up Thinking Politics}

The principles in the cooperative bottom-up thinking politics are the rule of relation and the accountability of professional qualification bottom-up and equally for everyone. The cooperative bottom-up thinking politics is well-off democracy based on wellbeing. The top-down rule by relation is a method that governments and people in power use to shape the cooperative behavior of people as kin-friends. In the bottom-up rule of relation, all people, including people in power and people at the lowest level of citizenship, are all equal under the relation itself. No one is excluded from the relation, and any relation that is excluded should be equally repaired across the board, regardless of status in society or local community. Rational competitors engage in rational checks and balances, while rational kin-friends engage in rational division of labor. Kin-friends are happy to be included in wellbeing, while competitors are happy in liberty to compete.

For the cooperative bottom-up thinking politics, the citizens are kin-friends, and to be included in the wellbeing among kin-friends is the goal of the constitution. To achieve the goal of inclusion of all people in wellbeing, the rule of relation in terms of everyone's role and effort is under continuous examination, openness, and reform. The foundation of the rule of relation is in family and community. Therefore, the rule of relation in family and community is heavily promoted to make sure people understand and appreciate family root and community root and to behave properly in the rule of relation in family and community. 
The rule of relation is not strict, because it is mixed with the rule of law. Competition stimulates examination, openness, and reform, so competition is necessary. The rule of law manages competition orderly and rationally. However, the liberty to compete at the expense of wellbeing is forbidden under the rule of relation. Overall, wellbeing dominates liberty, and the rule of relation dominates the rule of law. Under the rule of relation, the rule of law has limited independence to avoid the liberty to compete at the expense of wellbeing.

The bottom-up accountability of professional qualification is inclusive accountability for all citizens as kin-friends, while the top-down accountability by professional qualification is elite accountability for elite citizens as elite kin-friends. The Industrial Revolution transformed elite accountability by professional qualification into inclusive accountability of professional qualification. India abolishes the caste system by birth due to the Industrial Revolution and the lack of the religious foundation of the caste system in the Vedas which has the Varna system by choice instead of the caste system by birth. The accountability of professional qualification in China for the positions in government is established through the national education system, examination system, training system, and promotion system.

The accountability of professional qualification is not strict, because it is mixed with the accountability of election. Under the cooperative accountability of professional qualification, the accountability of election is cooperative democracy by election without partisan competition. Without partisan competition, only one party manages the election. The accountability of election is necessary to avoid absolute ruler. Generally, election by the public is at the local level, and election by representatives is at the higher level as described by Daniel A. Bell's "The China Model: Political Meritocracy and the Limits of Democracy" [53]. In China in 1978, Deng Xiaoping started well-off democracy by establishing the goal of moderately well-off society through reform and opening which involved cooperative rule of relation and accountability of professional qualification.

\subsection{The Multilateral Bottom-Up Thinking Politics}

The current global politics is multilateral with multiple nations and political systems. Since the end of the Cold War in early 1990s, competitive liberal democracy has become a major political system as described in "The End of History" [54] by Fukuyama who claimed that the human history was ended with liberal democracy and private free market economy. However, competitive liberal democracy has not dominated the world. According to the Democracy Index by the Economist Intelligence Unit (the world's leading resource for economic and business research) [55], in 2018, only 20 countries (4.5\% of the world population) are "full democracies", 55 (43.2\%) are "flawed democracies", 39 (16.7\%) are "hybrid regimes (illiberal democracy)", and 53 (35.6\%) are "authoritarian regimes". Full democracies are nations (mostly Northern and Western European countries) where civil liberties and basic political freedoms are not only res- 
pected, but also reinforced by a political culture conducive to the thriving of democratic principles. Flawed democracies are nations (mostly the USA, Central European, Southern American, and the Eastern Asian countries) where elections are fair and free and basic civil liberties are honored but may have issues (e.g. media freedom infringement). Hybrid regimes are nations (mostly African, Central Asian, and Eastern European countries) where consequential irregularities exist in elections, regularly preventing them from being fair and free. Authoritarian regimes are nations (many locations) where political pluralism has vanished or is extremely limited. These nations are often absolute monarchies or dictatorships, may have some conventional institutions of democracy but with meager significance, infringements and abuses of civil liberties are commonplace, elections (if they take place) are not fair and free, the media is often state-owned or controlled by groups associated with the ruling regime, the judiciary is not independent, and there are omnipresent censorship and suppression of governmental criticism. The 2017 Democracy index registered the worst year for global democracy since 2010-11 in the aftermath of the global economic and financial crisis. In 2016, the United States was downgraded from a full democracy to a flawed democracy.

One major reason for such multiple political systems is different degrees of industrialization in different countries. The bottom-up thinking politics is a product of the Industrial Revolution. With a low degree of industrialization, some countries still practically practice the decentralized hierarchical tribalism politics without significant rule and accountability from the thinking brain. The hierarchical tribalism politics in the modern nation social structure produces a chaotic regime or authoritarian regime as described in the Democracy Index by the Economist Intelligence Unit. Some countries practice the top-down thinking politics for only the upper-class people. The top-down thinking politics for a top-down society in the modern nation social structure produces an unfair election to favor the upper-class people as hybrid democracy in the Democracy Index. Recently, in highly industrialized countries, such as the USA, the ubiquitous social media generates social media tribalism where the groups of politically homogeneous people live separately in social media [56]. In social media tribalism, people use mainly the emotional-instinctive brain without the thinking brain for rule and accountability. This social media tribalism is a major reason for the USA downgraded from a full democracy to a flawed democracy in the Democracy Index. Terrorism is the product of violent tribalism mainly from social media in industrialized countries.

All major traditional religions in their original forms are the centralized top-down thinking religions derived from the religions for real or imaginary mega empires. They use both the emotional-instinctive brain and the thinking brain. In the USA, evangelical Christianity is a Bible-based religion in its original form as a centralized top-down thinking religion, so it favors the centralized top-down thinking politics to follow strictly top-down Christian tradition. Mainline Christianity is a multilateral bottom-up thinking religion for multilateralism and 
all people, so it prefers the multilateral bottom-up thinking politics. Extreme Christianity is a tribal religion using mostly the emotional-instinctive brain, so it favors the hierarchical tribalism politics. Different religions follow mostly different politics.

The Democracy Index by the Economist Intelligence Unit rules on liberal democracy as the competitive bottom-up thinking politics based on liberty to compete. The two viable multilateral bottom-up thinking politics in the modern nation social structure are competitive liberal democracy based on liberty and cooperative well-off democracy (well-off socialism) based on wellbeing. In liberal democracy, liberty dominates wellbeing, while in well-off democracy, wellbeing dominates liberty. Well-off democracy as represented by the politics in mainland China forbids harmful social media tribalism, because harmful social media tribalism is belligerently divisive and harmful to wellbeing.

\subsection{The Evolution of Political Order in China}

The evolution of political order in China with all different types of politics represents the evolution of political order of the world. In China, the earliest archeological evidence of hominid (Homo erectus) who practiced the realistic egalitarianism politics under the band social structure (hunter-gatherer society with simple stone tools) is Yuanmou Man who lived in Yuanmou County in the southwestern province of Yunnan, China around 1.7 million years ago [57]. China was populated as early as 1.66 million years ago based on stone artifacts found in the Nihewan Basin in Yangyuan County, the northern province of Hebei, China [58]. The human evolution of political order started from realistic egalitarianism politics with the band social structure around 200,000 years ago in Africa. The human migration wave out of Africa after about 70,000 years ago produced the lasting spread of modern humans throughout the world. The remains of one of the earliest humans to inhabit China is Tianyuan man who lived at the Tianyuan Cave near Beijing, China about 40,000 years ago [59]. The Upper Paleolithic Revolution to start the imaginative archaeological evidence egalitarianism politics under the linked band social structure occurred between 10,000 and 40,000 years ago before the Agricultural Revolution.

The earliest known Neolithic site for the rice cultivation in eastern China is at Kuahuqiao near Xianghu village, Xiaoshan District, in suburban Hangzhou, Zhejiang, China in 7700 years ago [60]. In China, the earliest bronze artifacts have been found in the Majiayao culture site (between 3100 and 2700 BC) who lived primarily in the upper Yellow River region in eastern Gansu, eastern Qinghai, and northern Sichuan, China [61]. With the Agricultural-Bronze Revolution, China started the decentralized hierarchical tribalism under the tribe social structure in about 5000 years ago. The decentralized hierarchical tribalism politics can be the orderly decentralized hierarchical tribalism politics with the peaceful tribe social structure under the effective control of one central overlord tribe or the disorderly decentralized hierarchical tribalism politics with the war- 
ring tribe social structure under no effective control of one central overlord tribe. The first legendary emperor in China under the orderly decentralized hierarchical tribalism politics is Huang Di (the Yellow Emperor 2711-2598 BC) who lived in the region of River Ji around Qingdi, Shaanxi, China. The first dynasty of the orderly decentralized hierarchical tribalism politics with archeological evidence is Xia (2070-1600 BC). It was followed by Shang (1600-1046 BC) and Zhou (1046-221 BC).

The last part of Zhou was under the disorderly decentralized hierarchical tribalism politics with the warring tribe social structure without effective control of one central overlord tribe. It consisted of the Spring and Autumn period (771-475 BC) and the Warring States period (475-221 BC). During these periods, the Iron Revolution in China began in $600 \mathrm{BC}$ to provide the resource to establish the centralized mega empire in China [62]. Each of the large states-tribes engaged in continuous wars to become the centralized mega empire in China. As a result, the constant conflict and need for innovative social and political models for the centralized mega empire led to the period of the Hundred Schools of Thought producing great thinkers. The most notable schools of thought include Mohism by Mozi, Confucianism by Confucius (551-479 BC), Mencius and Xunzi, Legalism by Shang Yang, Shen Buhai, Shen Dao and Han Feizi, and Daoism by Zhuangzhi and Laozi.

The first emperor of the centralized top-down thinking politics in China is Qin Shi Huang (259-210 BC), the First Emperor of Qin (221-206 BC). He adopted Legalism with the rule by law and the accountability by professional qualification under competitive worldview. Qi ended shortly after the death of Qin Shi Huang. Qi was followed by Han (202 BC-220 AD). Han adopted both Confucianism and Legalism with the rule by relation, the rule by law, and the accountability by professional qualification. The rule by relation with cooperative worldview dominated the rule by law with competitive worldview. China had the centralized top-down thinking politics under the centralized empire social structure from $221 \mathrm{BC}$ to $1911 \mathrm{AD}$ as the longest continuous political system.

In the late $19^{\text {th }}$ century, China started industrialization slowly, which allowed and required increasingly more young Chinese to receive modern education in China and overseas. Consequently, with modern education, Sun Yat-sen and Mao Zedong started the bottom-up revolution for all people to replace the centralized top-down thinking politics for the upper-class people in 1912 and 1949. After World War II, the fast advances in industrial technology have enhanced wealth and globalization greatly, resulting in the global increase in wealth. In 1978, Deng Xiaoping started well-off democracy by establishing the goal of moderately well-off society through reform and opening which involved cooperative rule of relation and accountability of professional qualification. (In terms of professional qualification, Deng Xiaoping famously said that it doesn't matter if a cat is black or white so long as it catches mice.) Since 1978, mainland China has eradicated poverty at the rate of poverty reduction and at the number of 
poor people reduction unmatched anywhere and anytime in the world. Mainland China continues actively to industrialize and to eradicate poverty especially in the poor and remote rural areas as an important national goal. The multilateral bottom-up thinking politics is practiced in China where mainland China has well-off democracy, and Hong Kong, Macau, and Taiwan have liberal democracy.

\subsection{The Evolution of Political Order in Israel}

The first legendary leader of Israel with the orderly decentralized hierarchical tribalism politics under the tribe social structure is Moses (1527-1407 BC) who led Israelites out of Egypt. After 40 years in the Sinai desert, Moses led them to the Land of Israel as the land promised by Yahweh to the descendants of the patriarchs, Abraham, Isaac, and Jacob. The earliest archeological evidence of Israel as a group was found on the Egyptian stela of Merneptah in about 1208 BC which seems to refer Israel at most to some ill-defined tribal federation. (The stela is the earliest textual reference to Israel and the only reference from ancient Egypt [63].) The time period is the Age of the Judges (1380-1045 BC) in the Bible. Therefore, the first real period with archeological evidence is the Age of the Judges.

The period from 1000-587 BC is known as the "Period of the Kings". The most noteworthy kings were King David (1010-970 BC). During this period before the coming of mega empires, Israel practiced decentralized hierarchical tribalism politics and religion. Israel was a tribe-state in a large region of Canaan. Each tribe in Canaan had its own deity under the chief deity whose name was El, resulting in polytheism. In polytheism, the chief deity was typically remote, and people worshiped their local deities. The local deity of Israel was Yahweh. All religions in Canaan were similar in terms of polytheism under the chief deity as shown from the Mesha Stele set up in 840 BC by King Mesha of Moab (a kingdom located in modern Jordan) [64] and from the Ugaritic texts written by the Late Bronze Age kingdom of Ugarit located on the coast of Syria [45].

The Iron Revolution produced mega empires, such as Assyria and Babylonia that destroyed all small nations, such as Israel. The destruction of Israel by the mega empires, Assyria and Babylonia, transformed tribal Israel into the imaginary mega Kingdom of Yahweh that controlled imaginarily all nations as described by the Prophet Isaiah in Isaiah 19:23-25: "In that day there will be a highway out of Egypt to Assyria, and the Assyrian shall come into Egypt, and the Egyptian into Assyria; and the Egyptians will worship with the Assyrians. In that day, Israel will be the third with Egypt and with Assyria, a blessing within the earth; because Yahweh of Armies has blessed them, saying, "Blessed be Egypt my people, Assyria the work of my hands, and Israel my inheritance." The fall of Israel was the beginning of the Kingdom of Yahweh. The leaders of the Kingdom were Yahweh and the prophets (thinkers) such as Isaiah. The Kingdom of Yahweh practiced the centralized top-down thinking politics under the mega empire social structure. 
The Kingdom of Yahweh is a top-down kingdom. The Industrial Revolution led to the bottom-up revolution that produced the bottom-up secular Zionist movement in the late 19th century by secular Jews who thought about Israel outside of realm of the top-down Kingdom of Yahweh. This secular bottom-up Zionist movement established the secular State of Israel that terminated the Kingdom of Yahweh in Israel in 1947. The State of Israel practices the multilateral bottom-up thinking politics in terms of liberal democracy. The comparison of the evolutions of political order in China and Israel is shown in Table 5.

\section{Summary and Conclusion}

\subsection{Summary}

The paper proposes that the four-component structure of political order consists of state, imagination, rule, and accountability whose mental origins are the social brain, theory of mind, the rational brain, and the empirical brain, respectively. This paper posits that in the evolution of political order, the main function of political order is to pacify changed social structure derived from technological revolution. Therefore, the four technological revolutions (the Upper Paleolithic, Agricultural-Bronze, Iron, and Industrial Revolutions) produce the four changed social structures (linked bands, tribe, mega empire, and modern nation, respectively) whose internal conflicts to be pacified by the four political revolutions

Table 5. The evolutions of political order in China and Israel.

\begin{tabular}{|c|c|c|c|c|c|}
\hline social structure & politics & China & year & Israel & year \\
\hline 1. tribe & $\begin{array}{c}\text { decentralized } \\
\text { hierarchical } \\
\text { tribalism politics }\end{array}$ & & & & \\
\hline $\begin{array}{l}\text { first legendary } \\
\text { leader }\end{array}$ & & Huang Di & $2711-2598$ BC & Moses & $1527-1407 \mathrm{BC}$ \\
\hline first real period & & $\mathrm{Xia}$ & $2070-1600$ BC & Judges & $1380-1045$ BC \\
\hline last period's end & & Zhou & $221 \mathrm{BC}$ & Judah & $587 \mathrm{BC}$ \\
\hline 2. mega empire & $\begin{array}{c}\text { centralized } \\
\text { top-down thinking } \\
\text { politics }\end{array}$ & & & & \\
\hline first leader & & Qin Shi Huang & $221 \mathrm{BC}$ & $\begin{array}{c}\text { Yahweh and } \\
\text { prophets }\end{array}$ & $587 \mathrm{BC}$ \\
\hline first period & & Qi & $221-206$ BC & $\begin{array}{l}\text { Kingdom of } \\
\text { Yahweh }\end{array}$ & $\begin{array}{c}587 \mathrm{BC}-1947 \\
\mathrm{AD}\end{array}$ \\
\hline last period's end & & Qing & $1912 \mathrm{AD}$ & $\begin{array}{l}\text { Kingdom of } \\
\text { Yahweh }\end{array}$ & $1947 \mathrm{AD}$ \\
\hline $\begin{array}{l}\text { 3. modern } \\
\text { nation }\end{array}$ & $\begin{array}{c}\text { multilateral } \\
\text { bottom-up thinking } \\
\text { politics }\end{array}$ & & & & \\
\hline first period & & $\begin{array}{l}\text { Republic of } \\
\text { China }\end{array}$ & $1912 \mathrm{AD}$ & State of Israel & $1947 \mathrm{AD}$ \\
\hline second period & & $\begin{array}{l}\text { People Republic } \\
\text { of China }\end{array}$ & $1949 \mathrm{AD}$ & & \\
\hline
\end{tabular}


(the imaginative, hierarchical, thinking, bottom-up political revolutions, respectively, for the imaginative egalitarianism, decentralized hierarchical tribalism, centralized top-down thinking, and multilateral bottom-up thinking politics, respectively).

According to Dunbar, the size of the human social brain is adapted to the manageable group size of about 150 people (Dunbar's Number) which was the group size of the prehistoric hunter-gatherer society dependent only on state derived from the social brain. The politics was realistic egalitarianism politics with bad as social structure and people as actual rulers. After the Upper Paleolithic Revolution, the prehistoric band social structure was converted into linked band social structure by the use of complex tools. The internal conflict resulted from linked bands with group size much larger than 150 people was pacified by the imaginative political revolution through religious imagination derived from theory of mind which was originally used for division of labor. The politics was imaginative egalitarianism politics with people as actual rulers. After the Agricultural-Bronzed Revolution, the linked band social structure was converted into the tribe social structure. The internal conflict from the hierarchical tribe social structure was pacified by the hierarchical political revolution. The politics was decentralized hierarchical tribalism politics with tribal chiefs as actual rulers. After the Iron Revolution, the tribe social structure was converted into the centralized mega empire social structure. The internal conflict from the multiple tribes was pacified by the thinking political revolution through the rational brain for rule and the empirical brain for accountability. The thinking brain was originally used to deal with difficult problems. The politics was centralized top-down thinking politics with thinkers as actual rulers. After the Industrial Revolution, the empire social structure is converted into the modern nation social structure. The conflict from rise of individual rights is pacified by the bottom-up political revolution. The politics is the multilateral bottom-up thinking politics with people as actual rulers.

In the competitive West originated from Greece and Middle East, the rule of law is the rational rule of competition among competitors, and the accountability of election is the empirical accountability of competition among competitors. In the cooperative East originated from India and China, the rule of relation is the rational rule of cooperation among kin-friends, and the accountability of professional qualification is the empirical accountability of cooperation among kin-friends. For political order, the two viable politics are competitive liberal democracy based on liberty and cooperative well-off democracy (well-off socialism) based on wellbeing from cooperation. The summary of the evolution of political order is in Table 6.

\subsection{Conclusion}

The origin of human behaviors is the human brain. Human behaviors are controlled by human cultures which are the product of human cultural evolution. 
Table 6. The evolution of political order.

\begin{tabular}{|c|c|c|c|c|c|c|c|}
\hline $\begin{array}{c}\text { social } \\
\text { structure }\end{array}$ & $\begin{array}{l}\text { technological } \\
\text { revolution }\end{array}$ & politics & $\begin{array}{l}\text { actual ruling } \\
\text { class }\end{array}$ & $\begin{aligned} & \text { state } \\
&= \text { social } \\
& \text { brain }\end{aligned}$ & $\begin{array}{l}\text { imagination } \\
=\text { theory of } \\
\text { mind }\end{array}$ & $\begin{aligned} & \text { rule } \\
= & \text { rational } \\
& \text { brain }\end{aligned}$ & $\begin{aligned} & \text { accountability } \\
= & \text { empirical brain }\end{aligned}$ \\
\hline band & & realistic egalitarianism & people & $\sqrt{ }$ & & & \\
\hline linked band & Upper Paleolithic & $\begin{array}{c}\text { imaginative } \\
\text { egalitarianism politics }\end{array}$ & people & $\sqrt{ }$ & $\sqrt{ }$ & & \\
\hline tribe & Agricultural-Bronze & $\begin{array}{l}\text { decentralized hierarchical } \\
\text { tribalism politics }\end{array}$ & tribal chiefs & $\sqrt{ }$ & $\sqrt{ }$ & & \\
\hline $\begin{array}{l}\text { mega } \\
\text { empire }\end{array}$ & Iron & $\begin{array}{l}\text { centralized top-down } \\
\text { thinking politics }\end{array}$ & $\begin{array}{l}\text { top-down thinkers and } \\
\text { upper-class people }\end{array}$ & $\sqrt{ }$ & $\sqrt{ }$ & $\sqrt{ }$ & $\sqrt{ }$ \\
\hline $\begin{array}{l}\text { modern } \\
\text { nation }\end{array}$ & Industrial & $\begin{array}{l}\text { multilateral bottom-up } \\
\text { thinking politics }\end{array}$ & $\begin{array}{l}\text { bottom-up thinkers } \\
\text { and all people }\end{array}$ & $\sqrt{ }$ & $\sqrt{ }$ & $\sqrt{ }$ & $\sqrt{ }$ \\
\hline $\begin{array}{l}\text { competitive } \\
\text { worldview }\end{array}$ & & $\begin{array}{c}\text { liberal democracy based on } \\
\text { liberty }\end{array}$ & & $\sqrt{ }$ & $\sqrt{ }$ & rule of law & $\begin{array}{l}\text { accountability of } \\
\text { election }\end{array}$ \\
\hline $\begin{array}{l}\text { cooperative } \\
\text { worldview }\end{array}$ & & $\begin{array}{l}\text { well-off democracy } \\
\text { (well-off socialism) based } \\
\text { on wellbeing }\end{array}$ & & $\sqrt{ }$ & $\sqrt{ }$ & rule of relation & $\begin{array}{l}\text { accountability of } \\
\text { professional } \\
\text { qualification }\end{array}$ \\
\hline
\end{tabular}

Consequently, the mental origins and the evolution of political order improve the comprehension of current political order and the projection of future political order.

The political systems in the world today are complicated and confusing. The decentralized hierarchical tribalism politics, the centralized top-down thinking politics, and the multilateral bottom-up thinking politics coexist within one country and even within one family. In the same way, the decentralized hierarchical tribalism religions, the centralized top-down thinking religions, and the multilateral bottom-up thinking religions coexist within one country and even within one family. Only the multilateral bottom-up thinking politics and religions are adaptive in the modern nation social structure under the Industrial Revolution. The obsolete decentralized hierarchical tribalism politics and religions and the obsolete centralized top-down thinking politics and religions are maladaptive and will eventually become mostly extinct in the modern nation social structure under the Industrial Revolution, in the same way that obsolete tribalism politics and polytheism were maladaptive and became mostly extinct in the mega empire social structure under the Iron Revolution.

The Industrial Revolution also has produced completely new complicated and confusing issues. The three important complicated and confusing issues are the artificial sociality as social media, the artificial brain as artificial intelligence, and global warming. Humans have not dealt with the artificial sociality as social media which is distance-independent, time-independent, and nearly invisible. $\mathrm{Hu}$ mans can recognize and control a normal social group, but it is very hard to recognize and control a social media social group which is distance-independent, time-independent, and nearly invisible. In liberal democracy, uncontrolled invisible social media is dishonest and destructive in terms of fake news (rumor) 
and terrorism. The artificial brain is artificial intelligence which is much faster, more precise, more reliable, and higher capacity in memory than the human brain. The artificial brains gradually replace the human brains in many areas, resulting in the great changes in employment. The global warming derived from the Industrial Revolution has become increasingly disruptive, and has produced serious social and environmental problems. Uncontrolled artificial sociality as social media, artificial brain as artificial intelligent, and global warming are harmful to human wellbeing. The two viable multilateral bottom-up thinking politics are cooperative well-off democracy based on wellbeing and competitive liberal democracy based on liberty. The world gradually recognizes that to control properly artificial sociality as social media, artificial brain as artificial intelligent, and global warming from harming human wellbeing, the middle democracy in between cooperative well-off democracy and competitive liberal democracy is necessary. Therefore, the direction of political order is middle democracy between liberal democracy and well-off democracy based on the multilateral bottom-up thinking politics.

\section{Conflicts of Interest}

The authors declare no conflicts of interest regarding the publication of this paper.

\section{References}

[1] Francis, F. (2011) Origins of Political Order: From Prehuman Times to the French Revolution. Farrar, Straus and Giroux, New York, NY.

[2] Francis, F. (2014) Political Order and Political Decay: From the Industrial Revolution to the Globalization of Democracy. Farrar, Strauss, and Giroux, New York, NY.

[3] Chung, D. (2018) The Mental Protection System for Protective Behaviors: The Social Brain and the Mental Immune System. Journal of Behavioral and Brain Science, 8, 31-55. https://doi.org/10.4236/jbbs.2018.81003

[4] Frith, C. (2007) The Social Brain? Philosophical Transactions of the Royal Society B: Biological Sciences, 362, 671-678. https://doi.org/10.1098/rstb.2006.2003

[5] Hamilton, W. (1964) The Genetical Evolution of Social Behavior II. Journal of Theoretical Biology, 7, 17-52. https://doi.org/10.1016/0022-5193(64)90039-6

[6] Dunbar, R. (2009) The Social Brain Hypothesis and Its Implications for Social Evolution. Annals of Human Biology, 36, 562-572. https://doi.org/10.1080/03014460902960289

[7] Dunbar, R. (2016) The Social Brain Hypothesis and Human Evolution. Oxford Research Encyclopedia of Psychology. https://doi.org/10.1093/acrefore/9780190236557.013.44

[8] Cozolino, L. (2006) The Neuroscience of Human Relationships: Attachment and the Developing Social Brain. W.W. Norton \& Company, New York.

[9] Wilson, E.O. (2012) The Social Conquest of the Earth. W.W. Norton \& Company, New York.

[10] Chung, D. (2016) The Basic Principles of Kin Sociality and Eusociality: Human Evolution. Natural Science, 8, 8-19. https://doi.org/10.4236/ns.2016.81002 
[11] Erikson, E. and Erikson, J. (1998) The Life Cycle Completed. W.W. Norton \& Company, New York.

[12] Slater, C.L. (2003) Generativity versus Stagnation: An Elaboration of Erikson's Adult Stage of Human Development. Journal of Adult Development, 10, 53-65. https://doi.org/10.1023/A:1020790820868

[13] McAdams, D. and De St. Aubin, E. (1992) A Theory of Generativity and Its Assessment through Self-Report, Behavioral Acts, and Narrative Themes in Autobiography. Journal of Personality and Social Psychology, 62, 1003-1015. https://doi.org/10.1037/0022-3514.62.6.1003

[14] Chung, D.Y. (2018) The Eight Stages of Psychosocial Protective Development: Developmental Psychology. Journal of Behavioral and Brain Science, 8, 369-398. https://doi.org/10.4236/jbbs.2018.86024

[15] Turner, J.C. and Reynolds, K.J. (2010) The Story of Social Identity. In: Postmes, T. and Branscombe, N., Eds., Rediscovering Social Identity: Core Sources, Psychology Press, New York, 13-32.

[16] Cohen, T., Montoya, R. and Insko, C. (2006) Group Morality and Intergroup Relations: Cross-Cultural and Experimental Evidence. Personality and Social Psychology Bulletin, 32, 1559-1572. https://doi.org/10.4236/jbbs.2018.86024

[17] Hamlin, J., Mahajan, N. and Wynn, K. (2013) Not Like Me = Bad: Infants Prefer Those Who Harm Dissimilar Others. Psychological Science, 24, 589-594. https://doi.org/10.1177/0956797612457785

[18] Calarge, C., Andreasen, N. and O’Leary, D. (2003) Visualizing How One Brain Understands Another: A PET Study of Theory of Mind. American Journal of Psychiatry, 160, 1954-1964. https://doi.org/10.1176/appi.ajp.160.11.1954

[19] Kapogiannis, D., Deshpande, G., Krueger, F., Thornburg, M.P. and Grafman, J.H. (2014) Brain Networks Shaping Religious Belief. Brain Connectivity, 4, 70-79. https://doi.org/10.1089/brain.2013.0172

[20] Kapogiannis, D., Deshpande, G., Krueger, F., Thornburg, M.P. and Grafman, J.H. (2009) Cognitive and Neural Foundations of Religious Belief. Proceedings of the National Academy of Sciences, 106, 4876-4881. https://doi.org/10.1073/pnas.0811717106

[21] Scott, F. and Baron-Cohen, S. (1996) Imagining Real and Unreal Objects: Evidence of a Dissociation in Autism. Journal of Cognitive Neuroscience, 8, 371-382. https://doi.org/10.1162/jocn.1996.8.4.371

[22] Angus, D.J., de Rosnay, M., Lunenburg, P., Terwogt, M.M. and Begeer, S. (2015) Limitations in Social Anticipation Are Independent of Imaginative and Theory of Mind Abilities in Children with Autism but Not in Typically Developing Children. Autism, 19, 604-612. https://doi.org/10.1177/1362361314537911

[23] Chan, P.-C., Chen, C.-T., Feng, H., Lee, Y.-C. and Chen, K.-L. (2016) Theory of Mind Deficit Is Associated with Pretend Play Performance, but Not Playfulness, in Children with Autism Spectrum Disorder. Hong Kong Journal of Occupational Therapy, 28, 43-52. https://doi.org/10.1016/j.hkjot.2016.09.002

[24] Norenzayan, A., Gervais, W. and Trzesniewski, K. (2012) Mentalizing Deficits Constrain Belief in a Personal God. PLoS ONE, 7, e36880. https://doi.org/10.1371/journal.pone.0036880

[25] Heyes, C. (2015) Animal Mindreading: What's the Problem? Psychonomic Bulletin \& Review, 22, 313-327. https://doi.org/10.3758/s13423-014-0704-4

[26] Bloch, M. (2006) Why Religion Is Nothing Special but Is Central. Philosophical 
Transactions of the Royal Society B, 363, 2055-2061.

https://doi.org/10.1098/rstb.2008.0007

[27] Chung, D. (2016) Human Religious Evolution. Open Journal of Social Sciences, 4, 75-90. https://doi.org/10.4236/jss.2016.43013

[28] Tang, Y., Hölzel, B. and Posner, M. (2015) The Neuroscience of Mindfulness Meditation. Nature Reviews Neuroscience, 16, 213-225. https://doi.org/10.1038/nrn3916

[29] Norenzayan, A., et al. (2016) The Cultural Evolution of Prosocial Religions. Behavioral and Brain Sciences, 39, e1. https://doi.org/10.1017/S0140525X14001356

[30] Shilling, C. and Mellor, P. (1998) Durkheim, Morality and Modernity: Collective Effervescence, Homo Duplex and the Sources of Moral Action. British Journal of Sociology, 49, 193-209. https://doi.org/10.2307/591309

[31] Westen, D. (2008) The Political Brain: The Role of Emotion in Deciding the Fate of the Nation. Public Affairs, New York City.

[32] Zatrev, J. (2014) The Co-Evolution of Human Intersubjectivity, Morality, and Language. In: Dor, D., Knight, C. and Lewis, J., Eds., The Social Origins of Language, Oxford University Press, Oxford, UK, 249-266.

[33] Hill, K. (2011) Co-Residence Patterns in Hunter-Gatherer Societies Show Unique Human Social Structure. Science, 11, 1286-1289.

https://doi.org/10.1126/science.1199071

[34] Dunbar, R. (1993) Coevolution of Neocortex Size, Group Size and Language in Humans. Behavioral and Brain Sciences, 16, 681-694. https://doi.org/10.1017/S0140525X00032325

[35] Bar-Yosef, O. (2002) The Upper Paleolithic Revolution. Annual Review of Anthropology, 31, 363-393. https://doi.org/10.1146/annurev.anthro.31.040402.085416

[36] Dixson, A. and Dixson, B. (2011) Venus Figurines of the European Paleolithic: Symbols of Fertility or Attractiveness? Journal of Anthropology, 2011, Article ID: 569120. https://doi.org/10.1155/2011/569120

[37] Lewis-Williams, D. (2002) The Mind in the Cave: Consciousness and the Origins of Art. Thames \& Hudson, London, UK.

[38] Cunliffe, B. (2001) The Oxford Illustrated History of Prehistoric Europe. Oxford University Press, Oxford.

[39] Wunn, I. (2000) Beginning of Religion. Numen, 47, 417-453. https://doi.org/10.1163/156852700511612

[40] Peoples, H., Duda, P. and Marlowe, F. (2016) Hunter-Gatherers and the Origins of Religion. Human Nature, 27, 261-282. https://doi.org/10.1007/s12110-016-9260-0

[41] Steadman, L., Palmer, C. and Tilley, C. (1996) The Universality of Ancestor Worship. Ethnology, 35, 63-76. https://doi.org/10.2307/3774025

[42] Swanson, G. (1960) The Birth of the Gods: The Origin of Primitive Belief. University of Michigan Press, Ann Arbor, Michigan. https://doi.org/10.3998/mpub.6484

[43] Davies, P. (2010) Urban Religion and Rural Religion. In: Stavrakopoulou, F. and Barton, J., Eds., Religious Diversity in Ancient Israel and Judah, Continuum International Publishing Group, New York, 103-115.

[44] Stern, E. (2001) Archaeology of the Land of the Bible, Volume II: The Assyrian. Doubleday, New York.

[45] Smith, M. (2001) Untold Stories: The Bible and Ugaritic Studies in the Twentieth Century. Hendrickson Publishers, Peabody, Massachusetts.

[46] Bosworth, A. (1995) World Cities and World Economic Cycles. In: Sanderson, S.K., 
ed., Civilizations and World Systems, Alta Mira Press, Walnut Creek, CA, 206-227.

[47] Muhly, J. (2003) Metalworking/Mining in the Levant. In: Richard, S., ed., Near Eastern Archaeology, Eisenbrauns, Winona Lake, Indiana, 174-183.

[48] Nisbett, R. (2004) The Geography of Thought: How Asians and Westerners Think Differently ... and Why. Free Press, New York.

[49] Yuki, M., Maddux, W.W., Brewer, M.B. and Takemura, K. (2005) Cross-Cultural Differences in Relationship- and Group-Based Trust. Personality and Social Psychology. Bulletin, 31, 48-62. https://doi.org/10.1177/0146167204271305

[50] Nikiprowetzky, V. (1975) Ethical Monotheism. Daedalus, 104, 80-81.

[51] Schwab, K. (2017) The Fourth Industrial Revolution. Crown Publishing Group, New York.

[52] Stein, R. (2009) Rule of Law: What Does It Mean? Minnesota Journal of International Law, 18, 293-298. http://scholarship.law.umn.edu/faculty_articles/424

[53] Bell, D. (2015) The China Model: Political Meritocracy and the Limits of Democracy. Princeton University Press, Princeton, NJ.

[54] Fukuyama, F. (1992) The End of History and the Last Man. Free Press, New York.

[55] The Economist Intelligence Unit (2019) Democracy Index 2018: Me too? https://www.eiu.com/Handlers/WhitepaperHandler.ashx?fi=Democracy_Index_201 8.pdf\&mode $=$ wp \&campaignid $=$ Democracy 2018

[56] Chua, A. (2018) Political Tribes: Group Instinct and the Fate of Nations. Penguin Press, London.

[57] Zhu, R., et al. (2008) Early Evidence of the Genus Homo in East Asia. Journal of Human Evolution, 55, 1075-1085. https://doi.org/10.1016/j.jhevol.2008.08.005

[58] Zhu, R., et al. (2004) New Evidence on the Earliest Human Presence at High Northern Latitudes in Northeast Asia. Nature, 431, 559-562. https://doi.org/10.1038/nature02829

[59] Yang, et al. (2017) 40000-Year-Old Individual from Asia Provides Insight into Early Population Structure in Eurasia. Current Biology, 27, 3202-3208. https://doi.org/10.1016/j.cub.2017.09.030

[60] Zong, Y., et al. (2007) Fire and Flood Management of Coastal Swamp Enabled First Rice Paddy Cultivation in East China. Nature, 449, 459-462. https://doi.org/10.1038/nature06135

[61] Liu, L. and Chen, X. (2012) The Archaeology of China: From the Late Paleolithic to the Early Bronze Age. In: Yoffee, N., ed., Cambridge World Archaeology, Cambridge University Press, Cambridge, England. https://doi.org/10.1017/CBO9781139015301

[62] Charles, H. (1996) The Bronze Age of Southeast Asia. Cambridge University Press, Cambridge, England.

[63] Hasel, M. (1998) Domination and Resistance: Egyptian Military Activity in the Southern Levant, 1300-1185 BC. Brill Publishers, Leiden, Netherlands.

[64] David, A. (2018) When God Wasn't So Great: What Yahweh's First Appearance Tells about Early Judaism. Haaretz, 13 September, 2018, Tel Aviv, Israel. 